\title{
Social Technologies in Education - An Actor-Network Analysis
}

\author{
Bill Davey $^{1}$ and Arthur Tatnall ${ }^{2}$ \\ ${ }^{1}$ School of Business IT and Logistics, RMIT University, Australia \\ ${ }^{2}$ School of Management and Information Systems, Victoria University, Australia \\ Bill.Davey@rmit.edu.au, Arthur.Tatnall@vu.edu.au
}

\begin{abstract}
There are many opportunities for social technologies to create wider and more valuable educational communities. This paper presents an analysis of a Government initiative to create educational communities around schools in Victoria, Australia using social networking systems. The analysis, comparing several systems, shows that a number of factors, including interpretation of reactions by actors are crucial to the success of applications of social technologies in an educational setting.
\end{abstract}

Keywords: Social technologies, social networking, Ultranet, CASES, MySchool, schools, students, parents, teachers.

\section{Introduction}

It seems obvious that the addition of social-technology based software in an educational context would be readily adopted by schools and systems, but several studies [1,2] have shown that this 'obviousness' should always be challenged. While several authors suggest a new digital age of well-prepared consumers $[3,4]$ there are findings that cast doubt on the unsupported assumption of automatic adoption of new systems [5-7]. Sappey and Relf [8:19] believe that:

"Learning and teaching should be considered inseparable and always considered holistically in developing technology enhanced learning models."

For many years computer systems in schools have been built around the need to handle the large amount of administrative data relating to individual students and student cohorts. This is collected from many formal and informal sources including: student enrolments, observational surveys, early year interviews, running records, other formal testing and anecdotal notes [9]. Other educational data relating to school and student performance is also important.

\section{Three Computer Systems in Victorian School Communities}

The goal of this study was to examine three computer systems in use in Victorian schools: CASES21, the Ultranet and MySchool, and to investigate whether, and if so 
how, they contribute to school community involvement and whether this has a beneficial effect on education.

\subsection{CASES 21}

In Government schools in Victoria the Department of Education mandates use of CASES21 (Computerised Administrative System Environment in Schools) for school administrative purposes. CASES21 aims to provide school administration with secure access to data entry and reporting modules that support school administration and finance functions. CASES21 has two modules [10]:

- An Administration Module to provide student administration support, including the facility to manage: student and family data; student pastoral data; medical information; attendance; achievement; discipline/welfare; accident and incident data; activities (including excursions); school management information; basic timetabling; daily organisation; and school associations (e.g. Parents Club and School Council).

- A Finance Module that aims to assist schools to create and receipt family and student invoices, manage debtors and creditors, manage the school's asset register, process and manage the school's local payroll, manage school finances and budgets and generate appropriate financial reports.

The prime purpose of CASES21 is to enable reporting from schools back to the Department of Education. It runs only on the school administrative network, and an earlier version has been in use since the late 1980s [11]. It was developed as a tool for overall school administration and as a means of reporting back from schools to the Department of Education. No consideration was given to its use in school classrooms either to support teacher administrative functions or to enhance teaching and learning [11-13].

\subsection{The Ultranet}

The Ultranet was designed to support knowledge sharing across the 1,555 Victorian government schools with their 540,000 students and 40,000 teachers [14, 15]. It was launched in September 2010 and designed to provide facilities for informing parents about their children as well as for curriculum delivery and online learning and teaching [16]. The Ultranet is: "a student centred electronic learning environment that supports high quality learning and teaching, connects students, teachers and parents and enables efficient knowledge transfer." [17]. It has many of the features of a business extranet in that it is closed to people outside the Victorian government school community and requires a username and password to gain access. One major difference, however, is that with over half a million users, the Ultranet is larger than most business extranets [18].

The Ultranet's incorporates various Web 2.0 technologies so making it a closed, secure place on the Internet, accessible at any time by students, teachers and parents/guardians from the school community [19]. It was designed to allow students 
to access personalised learning activities and keep an ongoing record, allowing them to collaborate and communicate with students from their own school and from other Victorian government schools. They will be able to create learning portfolios and use online communication tools such as Wikis, blogs and discussion boards.

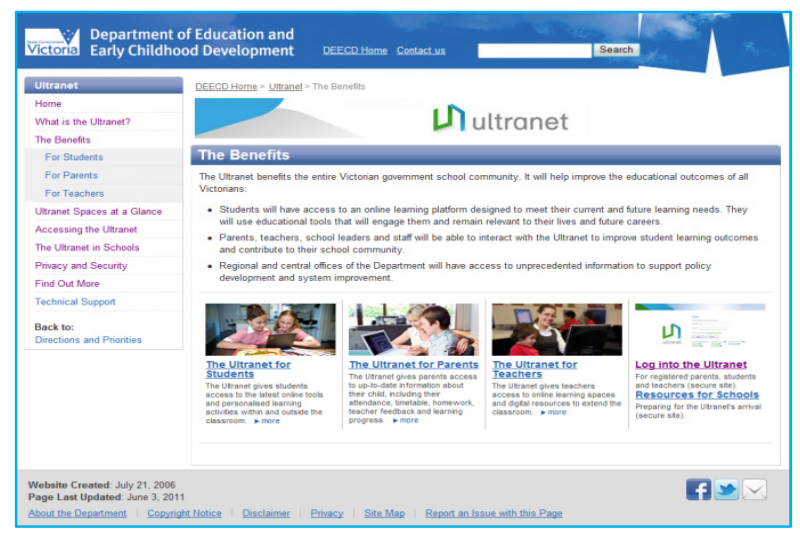

Fig. 1. The Victorian Education Ultranet (http://www.education.vic.gov.au/about/directions/ ultranet/benefits/default.htm)

The idea is that, using the Ultranet, teachers will be able to create curriculum plans, collaborate with other teachers, monitor student progress and provide assessment. The Ultranet will also assist parents in gaining benefits of flexible access to student information and school resources that will help them keep up-to-date with their child's learning. This dynamic student profile will include attendance records, test results, timetables, learning progress, homework activities, tasks, and feedback so providing a way for parents to support their child. These features should strengthen and extend parental involvement in schools and will result in richer more holistic and better negotiated approaches to student learning.

\subsection{MySchool}

The MySchool website provides a system designed to inform parents and the community about Australian schools [20]. It was set up by the Australian Government. (Although school education in Australia is a State responsibility, the Federal Government is also a significant actor in providing information and targeted grants to schools for specific projects.) Early in 2010 the Australian Government launched this new e-government initiative [21] that contains information about each of Australia's 10,000 primary and secondary schools, including: the number of students and teachers at the school and how the school is performing in national literacy and numeracy testing. The ideas of setting up MySchool was so: "parents and school communities would be able to compare their school's results with neighbouring schools and up to 60 statistically similar schools" [21] to see which schools are doing well and which schools are not. Data for this comes from NAPLAN (the National Assessment Program). 
MySchool is quite different to the Ultranet, however, in that it provides general information about all Australian schools, and not about particular students, to anyone who wants to see this. The aim is to allow parents to compare potential schools where they may want to send their children. MySchool also shows information on all Australian schools, both government and non-government whereas the Ultranet includes only Victorian government schools and aims to inform specific parents of their own school children.
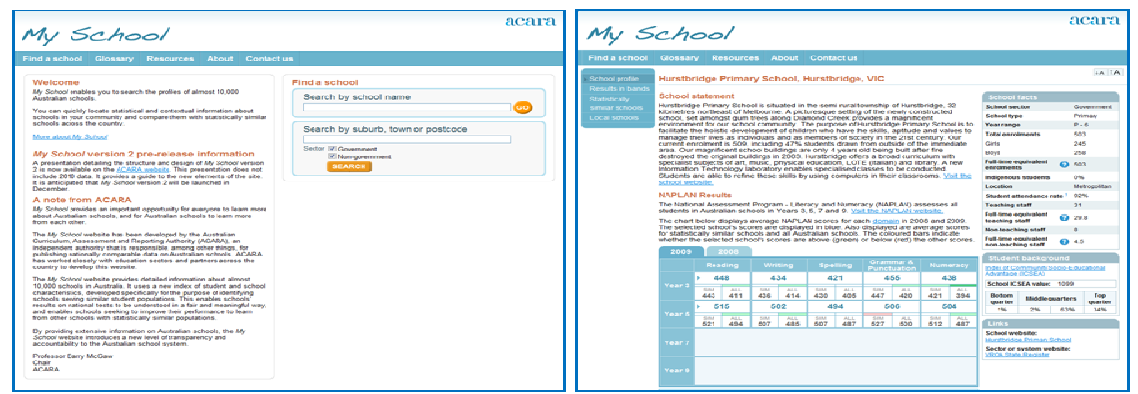

Fig. 2. MySchool website (http://www.myschool.edu.au/) showing information for Hurstbridge Primary School

\section{Research Framework and Methods}

Many approaches to socio-technical research treat the social and the technical in entirely different ways and as either: technologically driven or socially driven. A common approach is to focus on the technical aspects and to treat 'the social' as the context in which development and adoption take place. Actor-Network Theory (ANT), which originated from research in the social studies of science in the 1980s [22-24], was designed as an approach to socio-technical research that would treat the contributions of both human and non-human actors fairly and in the same way.

ANT considers the world to be full of hybrid entities containing both human and non-human elements. Questioning 'is it social?' or 'is it technical?' misses the point: the question should be 'is this association stronger or weaker than that one?' In this socio-technical order nothing is purely social and nothing is purely technical. ANT is concerned with studying the mechanics of power as this occurs through construction and maintenance of networks made up of both human and non-human actors [18]. In actor-network theory, an actor is any human or non-human entity that is able to make its presence individually felt by the other actors [25]. An actor is made up only of its interactions with these other actors, and a network can be hidden inside a 'black box' when its internal details are not under investigation.

If our research was into how students learn using these technologies we may have made use of a theory relating to learning with social technologies, a theory such as connectivism [26, 27]. Here, however, we are investigating adoption and use of these systems and in their use in creating educational communities, not their effectiveness 
in learning. For this purpose a lens that allows for contributions from both human and non-human actors is appropriate, and ANT fits well.

This research involved a study of the documentation of the three systems. A small number of people were interviewed to determine the range of relationships between the actors, including those interactions with the systems. Reports on the introduction of these systems including both official press reports and those from commentators also were used to find underlying relationships.

\section{$4 \quad$ An Actor-Network Analysis}

This study is especially interesting as all the human actors (schools, teachers, students and parents) are the same for each system so it is just the interactions with the nonhuman actors that lead to any new insights.

The first steps in any ANT analysis are to identify and 'interview' the actors. Although not complete the list of actors with significant relationships here included students, teachers, principals, parents, schools, State Government, National Government, The State Education Ministry (DEECD), the Internet and web tools and the three systems: Cases, MySchool and the Ultranet.

Table 1. CASES21, the Ultranet and MySchool

\begin{tabular}{|l|l|l|l|}
\hline & CASES21 & The Ultranet & MySchool \\
\hline Purpose & School administration & $\begin{array}{l}\text { Knowledge } \\
\text { sharing }\end{array}$ & $\begin{array}{l}\text { Comparison of } \\
\text { schools }\end{array}$ \\
\hline Usage & Schools must use & Encouraged & Voluntary \\
\hline $\begin{array}{l}\text { Year } \\
\text { introduced }\end{array}$ & 1988 & 2011 & 2010 \\
\hline $\begin{array}{l}\text { Main human } \\
\text { actors }\end{array}$ & $\begin{array}{l}\text { Principals, school } \\
\text { administrators, DEECD } \\
\text { staff }\end{array}$ & $\begin{array}{l}\text { Students, } \\
\text { teachers, } \\
\text { principals, } \\
\text { parents }\end{array}$ & Parents, students \\
\hline $\begin{array}{l}\text { Main non- } \\
\text { human actors }\end{array}$ & $\begin{array}{l}\text { CASES21, school } \\
\text { admin computers }\end{array}$ & $\begin{array}{l}\text { The Ultranet, } \\
\text { school and home } \\
\text { computers }\end{array}$ & $\begin{array}{l}\text { MySchool, } \\
\text { schools, home } \\
\text { computers }\end{array}$ \\
\hline Sponsor & $\begin{array}{l}\text { Education Department } \\
\text { (DEECD) Victoria }\end{array}$ & $\begin{array}{l}\text { Victorian } \\
\text { government }\end{array}$ & $\begin{array}{l}\text { Australian } \\
\text { government }\end{array}$ \\
\hline
\end{tabular}

\subsection{Relationships between Actors: Schools and Government}

Schools in Victoria have had a long tradition of independence in curriculum and in the delivery of their versions of the curriculum. In the last ten years or so, attempts have been made to standardise aspects of the curriculum but these have had little effect on how it is delivered. There is a political dichotomy between making schools self-governing and having sufficient control that governments can fulfil their accountability requirements to the electorate for education expenditure. Part of the decentralisation effort of government has been to grant more power to employ 
individual teachers to schools, but this is constrained by budgets. This decentralisation has been accompanied by attempts to make schools accountable for performance and a number of techniques such as a National Curriculum initiative and the National Testing Plan are being employed [28]. These changes are relatively new in Australia and the relationship between government and schools is still in flux. It would be fair to say that there is not complete trust between schools and government.

\subsection{Relationships between Actors: Schools and Teachers (Unions)}

Teachers in Victorian state schools are represented by the Australian Education Union (AEU). One of the recent campaigns by the union is the 'Stop league tables campaign' [29], resulting in the AEU submission to the 'Senate Education Employment and Workplace Relations Committee' into the 'Administration and Reporting of NAPLAN Testing' [30]. The union campaign is directed at preventing the Government having a more intrusive influence on teaching. One effect of the MySchool website seen as being a significant problem by the union was the possibility of the school changing its delivery as a result of poor showing in the National tests. The following was used as an explanation of behaviour seen as abhorrent:

"Teachers have been told by the Victorian Education Department to 'explicitly teach for NAPLAN', focus on literacy and numeracy and give students a 'daily NAPLAN item' in class ... The directive has led to accusations that Victorian education authorities are pressuring schools to 'teach to the test' to lift their performance on the new website at the expense of a broader curriculum." [31]

Significantly among their arguments is the contention that public release of information is not an absolute right of the public - presumably parents and other community interests. The AEU submission included evidence from Dr Ken Rowe of the Australian Council for Educational Research who wrote that:

“... it can be argued strongly that the public disclosure of information cannot be held to be an absolute principle." [30:29]

Our interviews with teachers showed that there is a general understanding that the teacher is the qualified person in the school community, but also the person with understanding of the local educational environment, and these two factors mitigate against anyone else having the right to significant input into school level decisions.

The Australian Newspaper of Dec $16^{\text {th }} 2009$ reported the desire of school principals to be given more rights to hire and fire teachers. This seems to provide evidence that teachers are seen as being antithetical to the idea of sharing power over school decisions.

The relationship between government and teachers can be seen as being instrumental in the fate of the three systems. CASES was constructed firstly to provide a single means of gathering data required by government from schools. In the knowledge that schools saw themselves as having significant data needs, the first version changes in CASES were to include modules that answered local school needs 
for the data being collected by government. In this way CASES began 'co-operating' with schools and teachers. MySchool, similarly recognised the power of teachers at the local level and completely bypassed them, communicating through the public website rather than normal communication channels, all of which required teacher involvement. The Ultranet seeks to involve teachers as part of the systems value, but has the problem of providing little help to teachers in their daily work and exposing them to local accountability that they have not experienced before. An ANT approach to this investigation considered all interactions between these actors as significant.

\subsection{Relationships between Actors: Teachers and Parents}

Our interviews indicated that teachers see several different types of relationships with parents. The first are with enthusiastic parents who want to be part of the school. At the primary school level these parents are involved with as many voluntary jobs as possible. These are mostly positions such as canteen worker, working bee participant and provider of reading help. A few are elected to the school council, an official, unpaid position with some governance duties for the school. The school council members do not have an easy or direct method for communicating with other parents and teachers do not see them as having the influence of an elected official with the backing of an electorate. By the secondary school level the amount of involvement of parents diminishes. There are still working bees and other volunteer jobs, but attendance involves a much lower proportion of families than for the primary level.

Secondly there are those parents who see the teachers as domain experts who take sole responsibility for student learning experiences. These parents will sign off homework and dutifully attend the occasional Parent Teacher meeting, general held once per term (semester) on a single evening for all families. These parents are happy to be directed as to what role to play and will openly become involved if they feel their 'consumer rights' have been infringed when their children perform less well than expected. The third parent image in the minds of teachers is of the disinterested. Teachers interviewed indicated that some parents were never seen and could not be relied upon to support teachers' decisions.

There was no indication from any teacher interviewed that parents were seen as having any ability to contribute to education outside support for homework or a talk about "what do firemen do" (or similar). Parents felt disenfranchised by school systems. There was not a lack of support for the school but questions about their involvement in real decisions produced either incomprehension at the idea or anecdotes about 'brick walls' placed in their path by the school.

These relationships have a significant impact on the chances of acceptance of two of the three systems. The CASES system has an impact on parents to the extent that the system provides the school with fast access to important information (from the Education Department). A parent without visiting rights (court injunctions) will be turned away at the front desk and a student with a medical condition will be treated properly with a single CASES query. To this extent CASES supports the relationship of professional and client that teachers see as the natural state. 
MySchool talks directly to parents and informs them of NAPLAN test results across their school. Teachers are armed with a number of explanations for shortfalls in performance - the problems of general statistics and such. They use these to prevent individual parent influence, but are being seen to react to MySchool in preparing students to improve results. There is no evidence outside our interviews, but it does seem that the one tactic considered by parents as a result of MySchool is to move children if the school performance is sub-par.

The Ultranet seeks to create a porous communications boundary between teachers and parents having the advantage of making the task of communicating with parents very easy for a teacher. The excuse for the 'grand occasion' parent/ teacher evening would be done away with. Teachers could become more aware of home circumstances and occurrences with little effort if parents were enticed to use the system. In our interviews teachers saw the system as being an extra workload burden in which they saw little value. Parents were not able to see anything on the system that would entice them to look, let alone contribute. This conclusion is to be doubted as the system is not fully functional as yet, but the functions that have been present for some time do seem to be ignored by both parties. The relationship between parents and teachers would lead us to conclude that the system will not progress past the present stage. It would not be in the interests of a teacher who claims absolute power over the education process to be completely candid with parents as that would presuppose parents could do something with any information they receive. Similarly a system that does not provide information is unlikely to have parents contributing. This would be especially true if they found their contributions not acted upon.

\section{Conclusion}

The CASES system was developed for accountability purposes to facilitate reporting from schools to the Department of Education. Its use is mandatory and it is not intended to provide support in school classrooms. The Ultranet is not just a single connection between government and the public, as is MySchool, but an attempt to create a mutually supporting educational community [19]. Its use is encouraged, but not mandated. MySchool was designed to provide information to parents about the school their children potential might attend. No regard was given to teachers as actors.

This paper has highlighted a number of important issues relating to the use of social technology in education, but we make no claim that these findings can be generalised to all other education systems. What makes a system valuable? Even systems provided available for no cost do not always persist, and the mandatory nature of some systems is not a reason for universal acceptance. When a system is seen as having value for its users it is likely to be adopted. This means we must consider that user scenarios are important when designing these systems. This paper has considered the question of who should be the actors: who should be the users of a system in a community and who should have input into its use? Should schools be regarded as central experts with no need for two way communication, or should social technology be allowed to give educational communities the opportunity to contribute? 


\section{References}

1. Botto, F., Passani, A., Kiran, Y.V.: Digital Ecosystems Adoption at Local Level: A Preliminary Comparative Analysis. In: Antonio Basile Colugnati, F., Lopes, L.C.R., Barretto, S.F.A. (eds.) OPAALS 2010. LNICST, vol. 67, pp. 76-91. Springer, Heidelberg (2010)

2. Stale, G., Cakula, S.: Application of enterprise modeling method for continuing education design and development. In: Proceedings of the 3rd WSEAS International Conference on Visualization, Imaging and Simulation, pp. 86-92. World Scientific and Engineering Academy and Society (WSEAS), Faro (2010)

3. Andone, D., Robu, N., Vasiu, R.: Building a Virtual Campus for digital students. In: Global Engineering Education Conference (EDUCON). IEEE, Amman (2011)

4. Castro, M., Colmenar, A., Martin, S.: Trends of Use of Technology in Engineering Education. In: Education Engineering (EDUCON). IEEE, Madrid (2010)

5. Ouf, S., Nasr, M., Helmy, Y.: An enhanced e-learning ecosystem based on an integration between cloud computing and Web2.0. In: Proceedings of the 10th IEEE International Symposium on Signal Processing and Information Technology, pp. 48-55. IEEE Computer Society (2010)

6. Johnson, G., Broadley, T.: Learning style and digital activity: An ecological study. In: ASCILITE 2011, Hobart (2011)

7. Margaryan, A., Littlejohn, A., Vojt, G.: Are digital natives a myth or reality? University students' use of digital technologies. Computers \& Education 56, 429-440 (2011)

8. Sappey, J., Relf, S.: Digital Technology Education and its Impact on Traditional Academic Roles and Practice. Journal of University Teaching \& Learning Practice 7(1) (2010)

9. Tatnall, C., Tatnall, A.: Using Educational Management Systems to Enhance Teaching and Learning in the Classroom: an Investigative Study. In: Tatnall, A., Okamoto, T., Visscher, A.J. (eds.) Knowledge Management for Educational Innovation, pp. 75-82. Springer, New York (2007)

10. Department of Education and Early Childhood Development. CASES21 (2011), http://www.education.vic.gov.au/management/ ictsupportservices/cases21/functionality.htm (January 2012)

11. Tatnall, A.: Information Technology and the Management of Victorian Schools Providing Flexibility or Enabling Better Central Control? In: Barta, B.Z., Telem, M., Gev, Y. (eds.) Information Technology in Educational Management, pp. 99-108. Chapman \& Hall, London (1995)

12. Davey, W., Tatnall, A.: Involving the Academic: A Test for Effective University ITEM Systems. In: Selwood, I., Fung, A.C.W., O’Mahony, C.D. (eds.) Management of Education in the Information Age: The Role of ICT, pp. 83-92. Kluwer Academic Publishers / IFIP, Assinippi Park, Massachusetts (2003)

13. Tatnall, A., Davey, W.: Open ITEM Systems are Good ITEM Systems. In: Nolan, P. (ed.) Institutional Improvement through Information Technology in Educational Management, pp. 59-69. Kluwer Academic Publishers, Dordrecht (2001)

14. Australian Bureau of Statistics. Statistics Victoria (Mar 2010), http://www.abs.gov.au/AUSSTATS/abs@.nsf/Lookup/1100.2Main+Features3Mar+2010 (November 2010)

15. Department of Education and Early Childhood Development. Summary Statistics for Victorian Schools (2010), http: / /www. education.vic.gov.au/about / publications/newsinfo/factsandfigures.htm (November 2010) 
16. Department of Education and Early Childhood Development. Ultranet - Students@Centre Trial (2010), http: / /www.education.vic.gov.au/about/directions / ultranet/trial.htm (November 2010)

17. Department of Education and Early Childhood Development. Ultranet (2010), http: / / www. education.vic.gov.au/management/ultranet/default.htm (May 2010)

18. Tatnall, A., Dakich, E.: Informing Parents with the Victorian Education Ultranet. In: Informing Science and IT Education. Informing Science, Novi Sad (2011)

19. Tatnall, A., Dakich, E., Davey, W.: The Ultranet as a Future Social Network: An Actor-Network Analysis. In: 24th Bled eConference. University of Maribor, Bled (2011)

20. Australian Curriculum Assessment and Reporting Authority. My School (2010), http: / / www . myschool . edu. au / Schoolsearch. aspx (November 2010)

21. Gillard, J.: My School website launched (2010), http://www. deewr.gov.au/ministers/gillard/media/releases / pages/article_100128_102905.aspx (May 2010)

22. Callon, M.: Some Elements of a Sociology of Translation: Domestication of the Scallops and the Fishermen of St Brieuc Bay. In: Law, J. (ed.) Power, Action \& Belief. A New Sociology of Knowledge? pp. 196-229. Routledge \& Kegan Paul, London (1986)

23. Latour, B.: The Powers of Association. In: Law, J. (ed.) Power, Action and Belief. A New Sociology of Knowledge? Sociological Review Monograph, vol. 32, pp. 264-280. Routledge \& Kegan Paul, London (1986)

24. Law, J.: The Heterogeneity of Texts. In: Callon, M., Law, J., Rip, A. (eds.) Mapping the Dynamics of Science and Technology, pp. 67-83. Macmillan Press, UK (1986)

25. Law, J. (ed.): A Sociology of Monsters. Essays on Power, Technology and Domination. Routledge, London (1991)

26. Siemens, G.: Connectivism: a Learning Theory for the Digital Age (2004), http: / / www. elearnspace.org/Articles/connectivism.htm (April 2012)

27. Siemens, G.: Knowing Knowledge (2006), http: / / www .elearnspace.org/ KnowingKnowledge_LowRes .pdf (April 2012)

28. Australian Curriculum Assessment and Reporting Authority. Naplan - National Assessment Program (2010), http: / / www . naplan.edu .au / home_page.html (January 2012)

29. Australian Education Union. Stop League Tables (2011), http: / /www . aeufederal .org.au/LT/index2.html (January 2012)

30. Australian Education Union, Australian Education Union Submission to the Senate Education Employment and Workplace Relations Committee into the Administration and Reporting of NAPLAN Testing. Australian Education Union, Melbourne (2010)

31. Perkins, M.: Teach for tests, teachers told (2010), http: / /www. theage.com.au/national/education/teach-for-teststeachers-told-20100204-ng6o.html (January 2012) 